\title{
Beyond participation? - Leadership ideals of future managers from Central and East European Countries
}

\author{
Rainhart Lang, Erna Szabo, Gheorghe Alexandru Catana, Zdeňka Konečná, \\ Petra Skálová*
}

This article analyses the leadership expectations of students in their role of potential future managers, comparing leadership prototypes across countries from Central and Eastern Europe with a focus on participative leadership. The findings suggest a complex web of influences, with individual value preferences being a particular strong predictor of students' participative leadership expectations. Compared with middle managers from GLOBE samples, the students' profiles match the participatory expectations of middle managers in their respective countries, but with a common tendency for managers to rank participative leadership more highly than students of the very country do.

Der Artikel analysiert Führungserwartungen von Studierenden in ihrer Rolle als künftige Manager, indem er Führungsprototypen mit einem Fokus auf partizipative Führung für verschiedene Länder Mittel- und Osteuropas vergleicht. Die Ergebnisse verweisen auf ein Netz von Einflüssen, in dem vor allem die individuellen Werte der Studierenden besonders bedeutsam sind. Im Vergleich mit mittleren Managern aus GLOBE-Studien zeigen sich Ähnlichkeiten, aber mit einer gemeinsamen Tendenz zu höherer Wertschätzung partizipativer Führung durch die mittleren Manager.

Key words: GLOBE, CEE countries, students, intercultural differences, leadership expectations, participative leadership, role models (JEL: J24, M14)

\footnotetext{
* Rainhart Lang, Full Professor, Department of Economics \& Business Administration, Chemnitz University of Technology, Germany. Main research interests: Leadership theories and cross cultural aspects of management and leadership, organisational change and transformation, managerial professions. Corresponding Address: r.lang@wirtschaft.tu-chemnitz.de

Erna Szabo, Associate Professor, Department of International Management, Johannes Kepler University Linz, Austria. Main research interests: Participative and ethical leadership, cultural intelligence, crossvergence, erosion of trust. Corresponding Address: erna.szabo@jku.at

Gheorghe Alexandru Catana, Full Professor, Technical University of Cluj-Napoca, Romania.Main research interests: Organisational behaviour, leadership, marketing. Corresponding Address: Alexandru.Catana @mae.utcluj.ro

Zdeňka Konečná, Ph.D., Senior Lecturer, Brno University of Technology, Faculty of Business and Management, Czech Republic. Main research interests: International human resource management, leadership across cultures, content and language integrated learning. Correspo nding Adress: konecna@fbm.vutbr.cz

Petra Skálová, Assistant Professor, Department of Business Administration and Management, Faculty of Economics, University of West Bohemia, Pilsen, Czech Republic. Main research interests: Human resource management, cross cultural aspects of management, ethical leadership, learning organisations, business economics. Corresponding Address: skalovap@kpm.zcu.cz
} 


\section{Introduction $^{11}$}

Leadership styles do not change quickly. As for the Central and Eastern European (CEE) countries, researchers (e.g. Lindert 1996, Edwards/Lawrence 2000; Reber et al. 2000; Steger/Winkler 2003; Steyrer et al. 2006; Lang et al. 2008) have repeatedly referred to the so-called "stickiness" of traditional or conservative leadership styles of the managers currently in charge in business organisations. The question is whether this pattern will change in the future with a new generation of young managers and leaders. On the one hand, and given the increasing influences of globalisation spread via mass and social media, one can expect a certain amount of convergence of values and leadership ideals across cultures and countries. On the other hand, today's young people are likely to hold a more critical stance than their parent generation toward the leadership practices currently in place in their cultures. This may be especially true for the high levels of power distance and low levels of participative leadership behaviour presently observable within the CEE region. Today's students are tomorrow's managers, most likely the ones currently enrolled in business economics and engineering studies. Consequently, it is of interest to find out more about the factors that have shaped their leadership expectations, specifically the drivers toward participative and other types of leadership expectations universally attributed as positive.

To our knowledge, no large-scale comparative studies have been conducted so far with respect to the leadership expectations of students - the potential future managers. Initial evidence stems from earlier phases of the GLOBE Student project (see Čater/Lang 2011). The current article expands the initial dataset by including a second Germanic country (Austria), as well as an additional Eastern European country (Poland). Both countries had also participated in the initial GLOBE project sampling data from middle managers in 61 societies (House et al. 2004; Chhokar et al. 2007). This overlap in datasets allows us to not only take a broader look at leadership ideals of Central and East European students, but also adds relevance to a manager vs. student comparison across cultures.

In more detail, we analyse the participative leadership prototypes of students in their role of potential future managers. From a country perspective, we compare leadership expectations by presenting country and country cluster profiles of participative leadership. From a hypothesis-testing perspective, we look at influence factors (in addition to national culture) on participative leadership,

11 The article is based on the data set of the GLOBE Student project. The project is co-ordinated by R. Lang (Chemnitz University of Technology, Germany). The research team also includes E. Szabo (Johannes Kepler University Linz, Austria), Z. Konečná (Brno University of Technology, Czech Republic), P. Skálová (University of West Bohemia, Pilsen, Czech Republic), R. Krzykała-Schaefer (Poznań School of Banking, Poland), D. Catana and G.A. Catana (Technical University of Cluj-Napoca, Romania), A. Lašáková and A. Remišová (Comenius University Bratislava, Slovakia), and T. Čater and D. Pučko (University of Ljubljana, Slovenia). 
specifically individual value preferences, age, gender, and field of study. We also test the influence of the institutional context as well as the role of social agencies and their respective role models, e.g. family/parents, school/teachers, peer group/friends. Finally, we discuss our data in comparison with the leadership prototypes of middle managers originating from the GLOBE project, and develop future research directions.

\section{Theoretical background and hypotheses}

As the GLOBE Student project builds on the initial GLOBE study, we share a common theoretical and methodological background, specifically with regard to implicit leadership theory (ILT) and its extension - culturally endorsed implicit leadership theory (CLT) (see for example Dorfman/House 2004; Dickson et al. 2012; Dorfman et al. 2012). In other words, we agree on the influence of societal culture on implicit leadership theories, i.e. leadership ideals. Additionally, we assume that socialising agents like parents, teachers, friends as well as leadership examples known from personal experience (e.g. superiors during internships) or from the media (e.g. politicians, successful business leaders, sports idols, scientists) play a role in shaping leadership expectations. Consequently, the GLOBE Student project builds on theories and models of socialisation to widen its theoretical basis (see Čater/Lang 2011, and the introduction article by Čater, Lang and Szabo in this special issue).

In more detail, current cross-cultural leadership research has focused on the influence of leadership prototypes and so-called implicit leadership theories (ILTs) on the perception and acceptance of managers in intercultural cooperation (e.g. House et al. 1999; House et al. 2004; Javidan et al. 2006; Chhokar et al. 2007; Dorfman et al. 2012). Particularly the GLOBE project strengthened the assumed link between national cultures and these leadership prototypes (House et al. 2004: 669-719; for an overview Dickson et al. 2012) by introducing culturally endorsed implicit leadership theories (CLTs). Leadership expectations are partly universal and partly depend on the cultural context: Participative leadership, for example, belongs to the culturally contingent attributes of leadership, while transformational or team oriented behaviours represent examples of universal leadership attributes (Brodbeck et al. 2000).

The GLOBE results have revealed similarities in leadership prototypes among cultures, for example among North European cultures and Germanic cultures in general (House et al. 2004: 669-719), and among Germanic (Central European) and East European cultures with regard to the expectation of autonomous leadership behaviour (see Szabo et al. 2001, 2002 for Germanic cultures; Bakacsi et al. 2002 for East European cultures). At the same time, significant differences have also been reported regarding culture and CLTs within Europe, with the Eastern and Southern parts of Europe on the one hand, and the Northern, Central and Western parts on the other hand (e.g. Brodbeck et al. 
2000; House 2002). The largest differences between Germanic (Central European) countries and East European countries concern a higher level of power distance by East European managers, together with a stronger expectation of participation by their German-speaking counterparts (see Weibler et al. 2000, Szabo et al. 2001, 2002 for Germanic cultures; Bakacsi et al. 2002 for CEE cultures). In this article we build on these findings and explore students' (future managers') similarities and differences in leadership prototypes in Germanic and East European countries. For this purpose, the following review of relevant studies provides the basis for developing meaningful hypotheses.

To our knowledge, only one study dealing with leadership expectations of students exists. Keating, Martin and Szabo’s (2002) study, comparing perceived cultural practices of students and managers in Austria and Ireland, reveals a stronger country than cohort/age effect: Significant differences regarding perceptions of cultural practices between the two country samples show for several dimensions, while the data display hardly any significant differences between managers and students of the same country (Keating et al. 2002: 646647). Despite these within-country overlaps among students and managers, the authors also point out the possibility of perceptions and attitudes of students changing once they start their organisational careers (p. 648).

Comparative studies do not only exist with regard to leadership prototypes, but also concerning perceptions of actual leadership behaviour. Here, differences show between Germany, Austria and CEE countries such as Estonia and Romania, mainly with respect to a more authoritarian and less participative style of CEE managers compared to German and Austrian ones (Lang et al. 2005; Steyrer et al. 2006; Lang et al. 2008). As for participative leadership, Alt and Lang (2004) also show that in a number of CEE countries local employees' leadership expectations differ considerably from the leadership realities applied by their German top managers, which may cause problems in direct interaction.

The leadership styles of managers in selected CEE countries, specifically the Czech Republic, Hungary and Poland, as experienced by Finnish expatriates, are described by Suutari and Riusala (2001). According to this comparison, Czech managers tend to be more active in criticising, role clarification and interaction facilitation than their Hungarian and Polish counterparts. Additionally, Czech managers are less active in informing, coordination, goal setting and providing vision, which may lead to the conclusion that Czech managers have a stronger preference for autocratic than participative leadership styles. Additionally, Suutari and Riusala (2001) point out differences between generations. What the data show for recently privatised companies (usually with younger managers) in comparison with state-owned organisations (usually with older managers) is more open communication, a smaller power distance between managers and subordinates and a stronger emphasis on achieving goals. This finding fits with 
our assumption of potentially changing leadership preferences, as described above.

According to the GLOBE data, power distance is among the cultural dimensions with fairly high scores for perceived practices, while at the same time the desired ideal reflects a much more egalitarian interrelation between social groups. Similar results also show in the first GLOBE Student analysis of five countries (Čater/Lang 2011: 98-100). As low power distance goes along with a rejection of autocratic leadership, we expect autocratic leadership styles to receive negative attributions from the students. At the same time, as GLOBE's measure of participative leadership builds on reverse-scored items targeting autocratic behaviour (compare Appendix A), we assume that students will evaluate participative styles positively.

In conclusion, the following hypotheses reflect the research reviewed above, specifically GLOBE's results on leadership ideals of managers in different countries, Keating, Martin and Szabo's (2002) study comparing managers and students in Austria and Ireland, and our own initial research in the context of the GLOBE Student project (Čater/Lang 2011).

Hypothesis 1: Students' leadership expectations will be in favour of participative leadership. At the same time, students will reject autocratic styles of leadership.

As pointed out above, the GLOBE study suggested differences between cultures in middle managers' appreciation of participative styles (House 2002; House et al. 2004), i.e. participative leadership is considered to be culturally contingent (e.g. Brodbeck et al. 2000; House 2002: 54). With regard to the CEE region, differences between Germanic (Germany and Austria) and East European countries were found for expected as well as for perceived leadership of middle managers (e.g. Szabo et al. 2002, Bakacsi et al. 2002 for expected leadership; Steyrer et al. 2006, Lang et al. 2008 for perceived leadership). In conclusion, country differences in participative leadership can be expected, especially for Austria and Germany on the one hand and the other CEE countries in our study on the other hand.

Hypothesis 2: The degree of participative leadership expectation will differ between countries. Especially Austrian and German students (Germanic cluster) will desire participative leadership more strongly than students in East European countries.

The initial analysis of GLOBE Student data from five countries suggested some influence of socio-demographic factors on participative leadership expectations (Čater/Lang 2011: 106-107). Firstly, female students were found to be more strongly in favour of participation than their male peers. Secondly, the younger the students were and the fewer study terms they had already spent at the university, the stronger their expectations of participative leadership. Finally, 
with regard to field of study, students of business economics held particularly strong expectations regarding the participative leadership ideal. We assume the same trends to hold true for the current seven-country dataset.

Hypothesis 3: Participative leadership expectations will be differently shaped according to age, gender, field of study, and number of study terms. We expect women, younger students and students with fewer study terms as well as business economics students to display a stronger wish for participative leadership than their fellow students.

The influence of individually held values (related to societal culture dimensions) on leadership expectations, i.e. culturally endorsed implicit leadership theories (CLTs), represents one of the conceptual cornerstones of the GLOBE project. Empirical results are supportive for different leadership dimensions including Participative Leadership (e.g. Dorfman et al. 2012: 507). Societal culture values related to Power Distance, Assertiveness, Institutional and In-group Collectivism, Humane Orientation and Gender Egalitarianism were also found influential in the five-country GLOBE Student study (Čater/Lang 2011: 108), although the initial analysis of student data also suggested that dimensions such as Value-based or Team-oriented Leadership are more strongly rooted in cultural values than participative leadership.

Hypothesis 4: Students' participative leadership ideals will be strongly related to the individual value preferences they hold. More specifically, low degrees of Power Distance and Assertiveness, as well as high levels of Institutional and In-group Collectivism, Humane Orientation and Gender Egalitarianism will go parallel with high expectations regarding participative leadership.

Consistent with the literature reviewed above, we assume that societal culture practices, as perceived by students, will have an additional impact on the leadership ideals they hold. The GLOBE study (House et al. 2004), as well as our own research (see e.g. country analysis for Slovakia by Remišová and Lašáková 2011: 46), lead us to assume the influence of cultural practices in the way stated in the following Hypothesis 5.

Hypothesis 5: Participative leadership expectations will be related to the perception of cultural practices in the respective country. In particular, high degrees of perceived Power Distance and Assertiveness will go parallel with comparatively low expectations of participative leadership, while established rules of Collectivism and Gender Egalitarianism will contribute to a comparatively high appreciation of participative behaviour.

If individual value preferences play an important role in shaping leadership expectations, early role models may also influence the development of students' leadership ideals. Among such agents of socialisation are parents, teachers, and friends during a child's socialisation in the family, in school and among peers 
(e.g. Hofstede 1991: 32-35; see also the introductory article by Čater, Lang and Szabo in this special issue). Depending on the experiences involved, role models may shape a young person's emerging ideal of leadership in the participative as well as non-participative direction. Furthermore, a student's superior during an internship, stars known from radio or TV, as well as business leaders, politicians, sports idols or successful scientists may serve as role models, too. In our initial analysis of student data, we found support for the influence of the above-mentioned groups (Čater/Lang 2011: 107-108) and assume similar tendencies for the current larger sample of students. Specifically, given potentially negative connotations with politics resulting from recent scandals and corruption, we expect strong participative leadership expectations to go along with a weak influence of politicians as role models. In contrast, science and research are usually highly valued in society. Consequently, scientists as role models should have a positive impact on participative leadership expectations.

Hypothesis 6: Students' attitudes toward participative leadership will be influenced by role models and experiences from family, school and peer groups, as well as leadership examples presented by the media. More specifically, experiences with participative decision processes in family, school and peer groups will contribute to an appreciation of participative leadership, and so will scientists as role models. In contrast, examples from politics will have a negative impact on participative leadership expectations.

Last but not least we are also interested in how students score in comparison to middle managers. Consequently, we need to compare our student data with the managerial results published by the original GLOBE project. In an initial comparison (Čater/Lang 2011) the clusters did not fully overlap. The current analysis provides a better basis, with student as well as managerial data available for Austria and Germany (Germanic cluster), as well as Poland, Slovenia and Romania (Eastern European cluster). Initial comparisons suggested that CEE students' participative leadership expectations are lower than expectations of middle managers in general, i.e. GLOBE's worldwide sample, and of managers in the corresponding Germanic and Eastern European clusters, specifically. This somewhat puzzling finding may have been related to the weakly matching datasets. It also contradicts Keating, Martin and Szabo's (2002) study, according to which Austrian as well as Irish students displayed significantly lower levels of Power Distance values than managers, implying that students should rate participative leadership more highly than managers. Nonetheless, we assume the initial GLOBE Student study's trend to hold true for the seven-country study, acknowledging that further data will be needed to fully explain the results, no matter what they are. 
Hypothesis 7: Students' participative leadership expectations will not be as high as the participation ideals of middle managers' from the same country.

The seven hypotheses are closely related to the conceptual basis of the GLOBE Student project (see introduction article by Čater, Lang and Szabo in this special issue) and are summarized in the following research frame (Figure 1).

Figure 1: Research frame

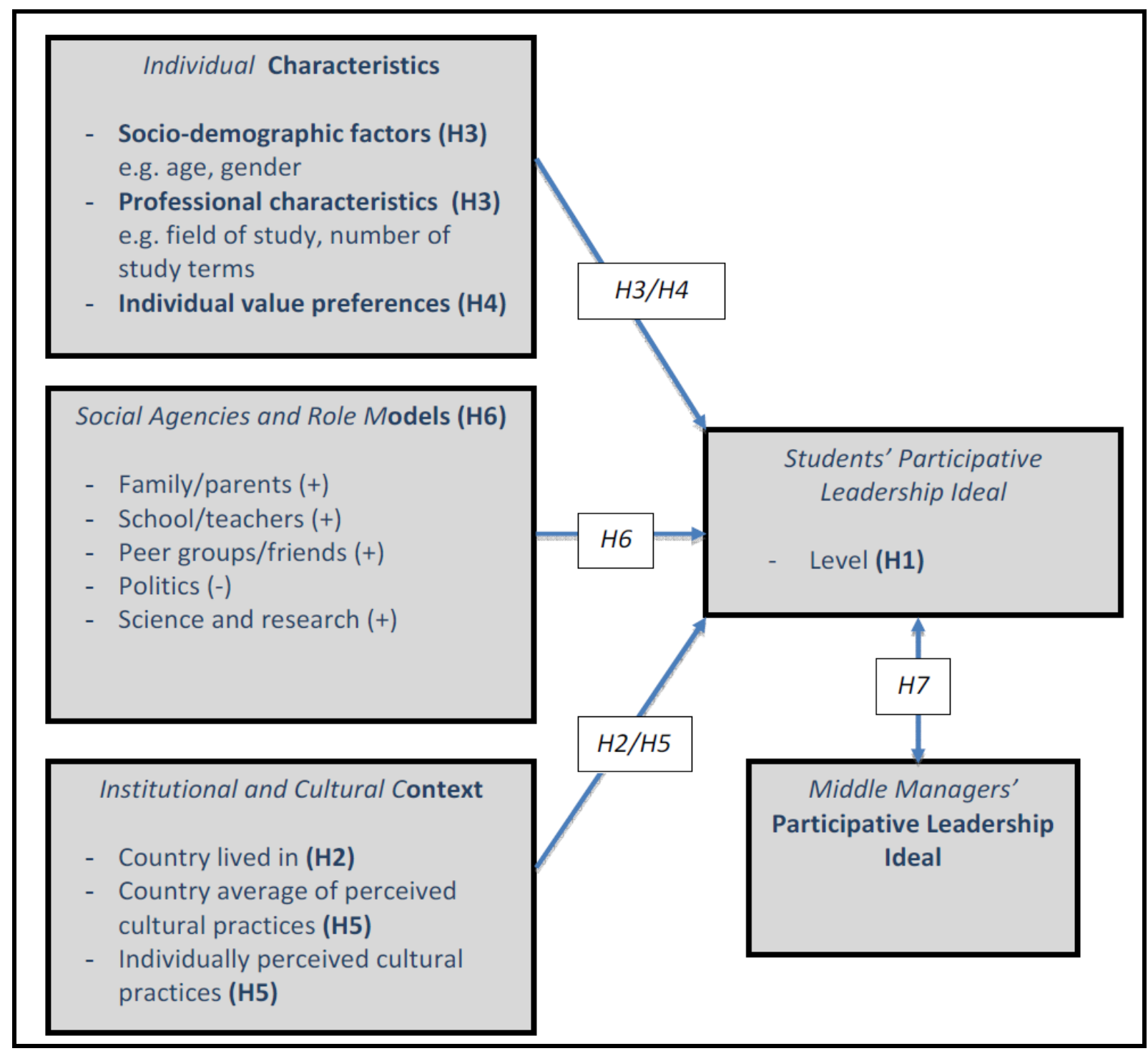

\section{Methods and sample}

The results presented in this article are generated from a database of 2356 students from Austria, Czech Republic, Germany, Poland, Romania, Slovakia and Slovenia, with at least 300 students representing each country. A modified Beta version of the original GLOBE leadership questionnaire was translated into the relevant languages and used for data collection. The questionnaire included socio-demographic items, GLOBE's measures for perceived societal culture 
practices ("as is") and values ("should be"), as well as GLOBE's scales and items targeting ideal leadership (see Appendices A and B for a list of the Participative Leadership scale's items). The leadership items reflected "traits, skills, abilities, and personality characteristics potentially relevant to leadership emergence and effectiveness" (Hanges/Dickson 2004: 126). Moreover, we added items related to the potential influence on one's values of role models from family, school, peer groups or job-related contexts (e.g. internships), as well as stars known from radio or TV, such as business leaders, politicians, sports idols or successful scientists. Sampling took place between 2008 and 2010. Detailed sample characteristics are presented in the Annex of the special issue.

For the calculation of the cultural dimensions, we followed the syntax suggested by the GLOBE Foundation (2006). For the value ("should be") dimensions we employed the individual scores of what students described as the desired state in their country/society. We also used the individual scores to measure their perceptions of cultural practices ("as is"). However, since earlier analyses (Čater/Lang 2011) suggest that individual perceptions of students seem to be of less importance for the development of their participative leadership ideals, and in order to get a more collectively shared view of a country's cultural and institutional context, we additionally used the country-average of students' perceptions of cultural practices for our analyses of the "as is" cultural dimensions.

When calculating the leadership dimensions we employed the original GLOBE syntax, but also a modified version for the Participative Leadership scale. In a first step we calculated the leadership prototype scales as suggested by the GLOBE authors (GLOBE Foundation 2006): A total of 112 leadership attributes, evaluated by the students on a scale from 1 to 7 , were grouped into 21 first-order "primary dimensions of leadership", which were then consolidated into 6 second-order "global leadership dimensions" (Dorfman et al. 2012: 506). In a second step we re-configured the original second-order Participative Leadership dimension (which had a Cronbach Alpha value below 0.6) by adding and taking out items in order to improve the quality of the scale (see results section below). A factor analysis revealed three subscales with conceptually different foci within the participative leadership construct.

To test the seven hypotheses, we ran SPSS procedures including descriptive statistics, cluster analyses, factor analyses, regression analyses and variance analyses. 


\section{Results}

\section{CEE students' leadership expectations in general and across countries}

Figure 2 illustrates the leadership expectations of the students in our sevencountry sample. Average scores above 4.0 indicate students' positive evaluations of a particular leadership style, while scores below 4.0 suggest behaviour inhibiting a person from being an effective leader, in the understanding of the students.

With an average score of 4.97, students rate Participative Leadership quite highly and contributing to effective leadership, although their first choice lies in other styles, namely in Team-oriented and Charismatic/Value-based Leadership with significantly higher scores of 5.69 and 5.56, respectively. With an average score of 4.53, Humane Leadership is also among the leadership dimensions positively evaluated by the students. The case is different for Autonomous Leadership. A closer look at the data shows that it is accepted by only slightly more than half of the students, while the others consider Autonomous Leadership behaviour to inhibit a person from being an effective leader. With an average score of 3.45, Self-protective Leadership is clearly rejected by the students.

Figure 2: CEE students' leadership preferences - to be placed here

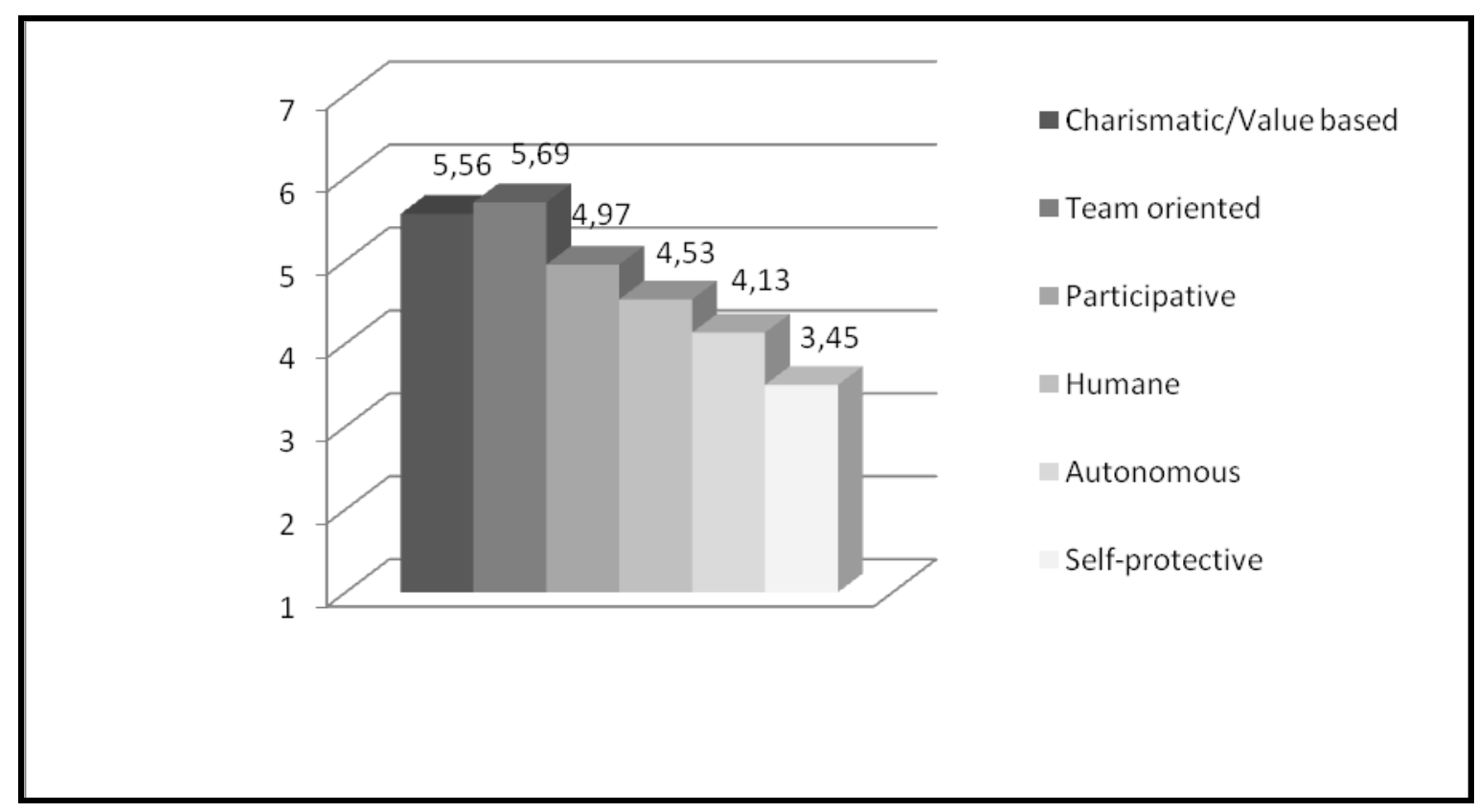

As GLOBE's global Participative Leadership dimension is calculated from reverse-scored items describing autocratic leadership behaviour (compare Appendix A), the data logically also reflect a negative attitude of the students with regard to the autocratic leadership style. More specifically, the individual item Autocratic as well as the first-order leadership dimension with the same 
name is rejected in all seven countries, with only slight but significant differences in the degree of rejection (See Table 2 below for details).

Table 1 shows the different profiles of expected leadership for the seven CEE student samples. All six global leadership dimensions show significant variation between countries. Parallel to GLOBE's managerial findings, Charismatic/Value-based, Team-oriented and Humane Leadership prototypes are still more similar (expressed by low F-values), while Autonomous and particularly Self-protective and Participative Leadership expectations are more culturally contingent. As for Participative Leadership specifically, Austrian and German students express the comparatively strongest preference for participation, followed by the Slovak students, while students from Slovenia and Romania express a considerably lower level of expected participative behaviour.

Table 1: Leadership preferences of CEE students by country

\begin{tabular}{|c|c|c|c|c|c|c|}
\hline & $\begin{array}{c}\text { Charismatic } \\
\text { /Value- } \\
\text { based }\end{array}$ & $\begin{array}{c}\text { Team- } \\
\text { oriented }\end{array}$ & $\begin{array}{l}\text { Participa- } \\
\text { tive }\end{array}$ & Humane & Autonomous & $\begin{array}{c}\text { Self- } \\
\text { protective }\end{array}$ \\
\hline $\begin{array}{l}\text { Austria } \\
\text { (AUT) }\end{array}$ & 5.53 & 5.47 & 5.30 & 4.44 & 4.14 & 3.09 \\
\hline $\begin{array}{l}\text { Germany } \\
\text { (GER) }\end{array}$ & 5.60 & 5.62 & 5.29 & 4.55 & 4.50 & 3.29 \\
\hline $\begin{array}{l}\text { Czech } \\
\text { Republic } \\
\text { (CZ) }\end{array}$ & 5.43 & 5.56 & 4.93 & 4.45 & 4.36 & 3.37 \\
\hline $\begin{array}{l}\text { Slovakia } \\
(\mathrm{SLV})\end{array}$ & 5.45 & 5.68 & 5.16 & 4.32 & 4.04 & 3.37 \\
\hline $\begin{array}{l}\text { Slovenia } \\
\text { (SLO) }\end{array}$ & 5.46 & 5.69 & 4.50 & 4.52 & 4.26 & 3.70 \\
\hline $\begin{array}{l}\text { Poland } \\
\text { (POL) }\end{array}$ & 5.48 & 5.82 & 4.86 & 4.66 & 4.24 & 3.58 \\
\hline $\begin{array}{l}\text { Romania } \\
\text { (ROM) }\end{array}$ & 5.76 & 5.89 & 4.77 & 4.73 & 3.66 & 3.72 \\
\hline Max.-Min. & 0.33 & 0.33 & 0.80 & 0.41 & 0.84 & 0.43 \\
\hline Average & 5.56 & 5.69 & 4.97 & 4.53 & 4.13 & 3.45 \\
\hline $\begin{array}{l}\text { Significance } \\
\text { of Country } \\
\text { Differences }\end{array}$ & $\begin{array}{c}F=12.156 \\
0.000\end{array}$ & $\begin{array}{c}F=18.050 \\
0.000\end{array}$ & $\begin{array}{c}F=36.645 \\
0.000\end{array}$ & $\begin{array}{c}F=10.425 \\
0.000\end{array}$ & $\begin{array}{c}F=24.410 \\
0.000\end{array}$ & $\begin{array}{c}F=59.339 \\
0.000\end{array}$ \\
\hline
\end{tabular}

Note: Means range from 1 (inhibiting effective leadership) to 7 (supporting effective leadership). 
These results support the hypothesised assumption of the participative leadership prototype's cultural contingency. Yet, we explored the data further to get an even more precise picture. The GLOBE questionnaire contained items potentially related to participative leadership beyond the ones already incorporated in the second-order dimension, as well as additional reverse-scored items reflecting autocratic behaviour. Table 2 shows the results of our investigation.

Table 2: Selected attributes conceptually related to CEE students' participative leadership expectations

\begin{tabular}{|c|c|c|c|c|c|c|c|c|c|}
\hline $\begin{array}{l}\text { Participative } \\
\text { Leadership } \\
\text { Item }\end{array}$ & $\begin{array}{c}\text { 7- } \\
\text { country } \\
\text { Mean }\end{array}$ & $\frac{\pi}{\underbrace{2}_{3}}$ & 导 & 胥 & 를 & $\frac{\pi}{\frac{\pi}{8}}$ & $\frac{a}{\ddot{z}}$ & 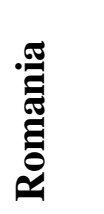 & $\begin{array}{c}\text { F- } \\
\text { Value } \\
\text { Sig. }\end{array}$ \\
\hline Autocratic & 2.65 & 2.42 & 2.47 & 2.60 & 3.18 & 2.36 & 3.38 & 2.33 & 0.000 \\
\hline Micromanager & 3.39 & 2.71 & 3.76 & 2.98 & 3.30 & 3.10 & 3.69 & 4.02 & 0.000 \\
\hline $\begin{array}{l}\text { Non- } \\
\text { delegating }\end{array}$ & 2.73 & 2.24 & 3.29 & 2.32 & 2.43 & 2.64 & 3.06 & 3.05 & 0.000 \\
\hline $\begin{array}{l}\text { Non- } \\
\text { participative }\end{array}$ & 2.29 & 2.14 & 3.04 & 2.22 & 2.21 & 2.42 & 1.88 & 2.15 & 0.000 \\
\hline $\begin{array}{l}\text { Non- } \\
\text { egalitarian }\end{array}$ & 2.69 & 2.57 & 2.77 & 2.96 & 2.75 & 2.48 & 2.73 & 2.58 & 0.002 \\
\hline $\begin{array}{l}\text { Individually } \\
\text { oriented }\end{array}$ & 3.51 & 3.37 & 3.15 & 3.37 & 3.94 & 3.36 & 3.30 & 3.85 & 0.000 \\
\hline $\begin{array}{l}\text { Non- } \\
\text { cooperative }\end{array}$ & 1.88 & 1.75 & 2.01 & 1.85 & 1.92 & 1.73 & 2.19 & 1.77 & 0.000 \\
\hline Consultative & 5.32 & 4.78 & 5.39 & 4.99 & 5.60 & 5.23 & 5.51 & 5.68 & 0.000 \\
\hline Collaborative & 5.78 & 5.68 & 5.73 & 5.75 & 5.84 & 5.83 & 5.68 & 5.94 & 0.006 \\
\hline
\end{tabular}

Notes: Scores range from 1 (inhibiting effective leadership) to 7 (supporting effective leadership); highest country score per item marked bold, lowest country score per item marked bold and italic.

The data show a strong rejection of various types of autocratic-related behaviour and support the above findings. Students especially rejected the attributes Noncooperative and Non-participative, as well as Autocratic and Non-egalitarian. Individually Oriented behaviour was slightly rejected, while the students gave preference to Consultative and Collaborative behaviour.

The item-level data presented in Table 2 also support the above findings concerning divergence between countries. Strongly significant differences between countries show especially for Micromanager $(F=35.846)$, Non- 
delegating $(\mathrm{F}=30.105)$, Autocratic $(\mathrm{F}=25.360)$, Non-participative $(\mathrm{F}=24.717)$ and Consultative $(\mathrm{F}=23.614)$. In addition, the data also point to quite different country profiles: In comparison with the other countries, the Austrian data for instance show a strong rejection of autocratic and non-delegating behaviour, but only a limited preference for consultative behaviour, while the Slovenian data display a particularly strong preference for egalitarian, collaborative and cooperative behaviour.

\section{Re-configuration of GLOBE's participative leadership dimension}

The statistics for GLOBE's second-order dimension with a Cronbach Alpha value below 0.6 and the relevance of additional items for interpreting participative leadership (compare Table 2) led us to the idea of re-configuring the factor. In a first step, we added as well as took out items to test whether this would improve the quality of the scale. We got a refined Participative Leadership dimension with a Cronbach Alpha of 0.677. The new scale included the reverse-scored items for Autocratic, Non-egalitarian, Individually Oriented, Non-delegating, Micro-managerial and Elitist from the original GLOBE dimension, and added the reverse-scored items Non-participative and Noncooperative. The items Bossy, Domineering, Ruling and Dictatorial were excluded for conceptual as well as empirical reasons, while new items like Collaborative and Consultative did not improve the scale and were removed again. This may suggest that students view, for example, consultations as conceptually different from participation in decision making.

In a next step we explored the sub-structure of the new Participative Leadership construct. A factor analysis led to a three-factor solution with around $60 \%$ explanation of the overall variance (Kaiser-Meyer-Olkin 0.750; sig. 0.000):

1. Autocratic vs. cooperative-participative decision behaviour ("Participative Decision Making”),

2. Non-delegating and micro-managing vs. delegating behaviour ("Nonelitist Delegating Behaviour"),

3. Individually-oriented vs. group-egalitarian orientation and behaviour ("Egalitarian Group Orientation").

The three factors describe different facets of participative behaviour, centred on the aspects decision making, delegation and equality. Table 3 shows the results for the newly calculated dimension and its three subscales. 
Table 3: New scales related to CEE students' participative leadership expectations by country

\begin{tabular}{|c|c|c|c|c|c|}
\hline & GLOBE & \multicolumn{4}{|c|}{ GLOBE Student: Re-configured Scales } \\
\hline & $\begin{array}{c}\text { Second-order } \\
\text { Participative } \\
\text { Leadership } \\
\text { Dimension }\end{array}$ & $\begin{array}{c}\text { New Second- } \\
\text { order } \\
\text { Participative } \\
\text { Leadership } \\
\text { Dimension }\end{array}$ & $\begin{array}{c}\text { Subscale 1: } \\
\text { Participative } \\
\text { Decision } \\
\text { Making }\end{array}$ & $\begin{array}{c}\text { Subscale } \\
\text { 2: } \\
\text { Non-elitist } \\
\text { Delegating } \\
\text { Behaviour }\end{array}$ & $\begin{array}{c}\text { Subscale 3: } \\
\text { Egalitarian } \\
\text { Group } \\
\text { Orientation }\end{array}$ \\
\hline $\begin{array}{l}\text { Austria } \\
\text { (AUT) }\end{array}$ & 5.30 & 5.33 & 5.80 & 5.21 & 4.81 \\
\hline $\begin{array}{l}\text { Germany } \\
\text { (GER) }\end{array}$ & 5.29 & 5.35 & 5.78 & 5.31 & 4.77 \\
\hline $\begin{array}{l}\text { Czech R. } \\
\text { (CZ) }\end{array}$ & 4.93 & 5.01 & 5.50 & 4.50 & 5.04 \\
\hline $\begin{array}{l}\text { Slovakia } \\
(\mathrm{SLV})\end{array}$ & 5.16 & 5.36 & 5.83 & 5.09 & 5.08 \\
\hline $\begin{array}{l}\text { Slovenia } \\
\text { (SLO) }\end{array}$ & 4.50 & 5.06 & 5.52 & 4.65 & 4.99 \\
\hline $\begin{array}{l}\text { Poland } \\
\text { (POL) }\end{array}$ & 4.86 & 5.18 & 5.57 & 5.16 & 4.65 \\
\hline $\begin{array}{l}\text { Romania } \\
\text { (ROM) }\end{array}$ & 4.77 & 5.15 & 5.92 & 4.63 & 4.78 \\
\hline Max.-Min. & 0.80 & 0.35 & 0.42 & 0.81 & 0.43 \\
\hline Average & 4.97 & 5.21 & 5.71 & 4.93 & 4.87 \\
\hline $\begin{array}{l}\text { Significance } \\
\text { of Country } \\
\text { Differences }\end{array}$ & $\begin{array}{c}F=36.645 \\
0.000\end{array}$ & $\begin{array}{c}F=10.181 \\
0.000\end{array}$ & $\begin{array}{c}F=10.951 \\
0.000\end{array}$ & $\begin{array}{c}F=29.186 \\
0.000\end{array}$ & $\begin{array}{c}F=5.928 \\
0.000\end{array}$ \\
\hline
\end{tabular}

Notes: Scores range from 1 (inhibiting effective leadership) to 7 (supporting effective leadership); highest country mean per scale marked bold; lowest country mean per scale marked bold and italic.

The higher complexity of the new Participative Leadership dimension leads to an obviously more differentiated picture. It shows a strong collective (!) wish and expectation of students for participation in decision making processes, with a weaker focus on delegating and egalitarian leadership behaviours. Table 3 also shows that expectations toward participation in decision making are more universally attributed and less divergent across countries. Delegating behaviour in turn seems to be more culturally contingent, at least for the groups of 
students. Additionally, the new second-order dimension seems to equalize the differences between the subscales, so that at this level differences between the countries diminish. Nonetheless, the data show that divergence is still present, especially in the above-mentioned area of delegation. In contrast to the original Participative Leadership dimension, the difference between the Germanic cluster and the Eastern European cluster no longer shows as clearly.

\section{Demographic characteristics and individual value preferences}

Slight gender differences between countries were found for the participative leadership measures, the original GLOBE second-order dimension as well as the newly calculated one $(>0.01 * *$ and $>0.05 *$, respectively): Female students displayed a stronger wish for participative leadership styles than their male counterparts. The data also indicate differences between age groups, specifically for the new subscale Non-elitist Delegating Behaviour, which seems to be of less importance to older students compared to younger ones (at a significance level of $>0.01 * *$ ). Minor effects regarding number of study terms point into the same direction and are obviously related to age. To explore the potential impact of professional socialisation, we tested the student sample for differences based on field of study. The analysis showed significant differences (with $>0.01 * *$ for both Participative Leadership dimensions as well as the three subscales) between business economics students on the one hand and engineering students on the other hand. Especially the Participative Decision Making ideal (Subscale 1) seems to be of higher importance to the students enrolled in business and economics studies.

As for individual value preferences students hold with regard to societal culture dimensions, Table 4 exhibits the correlations between student values and their participatory leadership expectations. All nine cultural "should be" dimensions show highly significant relationships with the newly calculated Participative Leadership dimension, and only Future Orientation was not found significantly correlated with GLOBE’s original second-order participative measure.

Table 4: Impact of individual value preferences on CEE students' participative leadership expectations

\begin{tabular}{|l|c|c|}
\hline $\begin{array}{l}\text { Individual Value } \\
\text { Preferences Regarding } \\
\text { Societal Culture } \\
\text { Dimensions }\end{array}$ & $\begin{array}{l}\text { Participative Leadership } \\
\text { (GLOBE's Second-order } \\
\text { Dimension) }\end{array}$ & $\begin{array}{l}\text { Participative Leadership } \\
\text { (New Second-order } \\
\text { Dimension) }\end{array}$ \\
\hline Uncertainty Avoidance & $-0.120^{* *}$ & $-0.092^{* *}$ \\
\hline Future Orientation & n.s. & $0.046^{*}$ \\
\hline Power Distance & $-0.406^{* *}$ & $-0.346^{* *}$ \\
\hline
\end{tabular}




\begin{tabular}{|l|l|l|}
\hline Institutional Collectivism & $0.182^{* *}$ & $0.193^{* *}$ \\
\hline Humane Orientation & $0.259^{* *}$ & $0.225^{* *}$ \\
\hline Performance Orientation & $0.183^{* *}$ & $0.218^{* *}$ \\
\hline In-group Collectivism & $0.229^{* *}$ & $0.252^{* *}$ \\
\hline Gender Egalitarianism & $0.223^{* *}$ & $0.229 * *$ \\
\hline Assertiveness & $-0.341^{* *}$ & $-0.209^{* *}$ \\
\hline
\end{tabular}

Note: ${ }^{* *} \mathrm{p}<0.01,{ }^{*} \mathrm{p}<0.05$

In more detail, the participative leadership ideals of CEE students seem to go hand in hand with a strong rejection of Power Distance and Assertiveness values, as well as strong and positive values related to In-group Collectivism, Humane Orientation and Gender Egalitarianism. In addition, the data also revealed a weaker yet significantly positive link with Performance Orientation and Institutional Collectivism, as well as a rejection of rule orientation, i.e. Uncertainty Avoidance values. Compared with the other dimensions, Future Orientation seems to be only weakly connected with students' participative leadership expectations.

Differences between the two differently calculated leadership dimensions were found with regard to the factor ranking, the missing correlation of Future Orientation with the original GLOBE participation scale, and a comparatively weaker link with Assertiveness values for the newly calculated Participative Leadership dimension compared to the original one.

In conclusion, the findings strengthen the (for managers already welldocumented) assumption that the cultural value set an individual holds is a strong predictor of her/his participative leadership preferences.

\section{Institutional and cultural practices}

In our data, the institutional and cultural context is displayed by the country a student lives in and her/his perceptions regarding the country's institutional and cultural practices, as represented by the GLOBE societal culture "as is" dimensions. As mentioned above, we employed two measures: (1) the countryspecific average of students' perceptions, and (2) students' individual perceptions.

Table 5 shows relevant influences of the institutional and cultural context, as measured by country averages, on participative leadership expectations for the re-configured dimension of Participative Leadership as well as the original GLOBE dimension. The influence of cultural practices, specifically weak Ingroup Collectivism, Gender Egalitarianism and Humane Orientation practices, pronounced Future Orientation practices and at the same time strong rule orientation (high scores on Uncertainty Avoidance and Institutional Collectivism 
practices) in combination with high Performance Orientation practices and distinctive Assertiveness practices seem to have an impact on GLOBE's secondorder Participative Leadership dimension. The correlations between countryaverage cultural practices and the new, re-configured Participative Leadership dimension point into the same direction, yet suggest a slightly weaker impact.

In contrast, when students' individual perceptions of cultural practices enter the analysis, significant correlations with the Participative Leadership dimensions show for only five of the nine cultural dimensions. Parallel to the country-level analysis, weak In-group Collectivism practices and high Future Orientation and Uncertainty Avoidance practices seem to support the participative leadership ideal (for both dimensions of Participative Leadership).

Table 5: Impact of the perceived institutional and cultural practices on CEE students' participative leadership expectations

\begin{tabular}{|c|c|c|c|c|}
\hline \multirow[t]{2}{*}{$\begin{array}{l}\text { Perceived } \\
\text { Institutional and } \\
\text { Cultural } \\
\text { Practices }\end{array}$} & \multicolumn{2}{|c|}{$\begin{array}{c}\text { Participative Leadership } \\
\text { (GLOBE's Second-order } \\
\text { Dimension) }\end{array}$} & \multicolumn{2}{|c|}{$\begin{array}{c}\text { Participative Leadership } \\
\text { (New Second-order } \\
\text { Dimension) }\end{array}$} \\
\hline & $\begin{array}{l}\text { Individual } \\
\text { Perceptions }\end{array}$ & $\begin{array}{l}\text { Country } \\
\text { Average }\end{array}$ & $\begin{array}{l}\text { Individual } \\
\text { Perceptions }\end{array}$ & $\begin{array}{l}\text { Country } \\
\text { Average }\end{array}$ \\
\hline $\begin{array}{l}\text { Uncertainty } \\
\text { Avoidance }\end{array}$ & $0.116 * *$ & $0.197 * *$ & $0.069 * *$ & $0.085^{* *}$ \\
\hline Future Orientation & $0.119 * *$ & $0.226 * *$ & $0.063 * *$ & $0.094 * *$ \\
\hline Power Distance & n.s. & $-0.117 * *$ & $0.046^{*}$ & $-0.050 *$ \\
\hline $\begin{array}{l}\text { Institutional } \\
\text { Collectivism }\end{array}$ & n.s. & $0.178 * *$ & n.s. & $0.063 * *$ \\
\hline $\begin{array}{l}\text { Humane } \\
\text { Orientation }\end{array}$ & $-0,051^{*}$ & $-0.160 * *$ & n.s. & $-0.044^{*}$ \\
\hline $\begin{array}{l}\text { Performance } \\
\text { Orientation }\end{array}$ & n.s. & $0.194 * *$ & n.s. & $0.059 * *$ \\
\hline $\begin{array}{l}\text { In-group } \\
\text { Collectivism }\end{array}$ & $-0.136 * *$ & $-0.247 * *$ & $-0.048 *$ & $-0.118 * *$ \\
\hline $\begin{array}{l}\text { Gender } \\
\text { Egalitarianism }\end{array}$ & n.s. & $-0.164 * *$ & $0.052 *$ & $-0.070 * *$ \\
\hline Assertiveness & $0.068 * *$ & $0.179 * *$ & n.s. & $0.094^{* *}$ \\
\hline
\end{tabular}

Note: ${ }^{* *} \mathrm{p}<0.01,{ }^{*} \mathrm{p}<0.05$

With regard to the three subscales of the new Participative Leadership dimension, the impact of perceived cultural practices on participatory 
expectations seems to be of high relevance especially for the subscale Nonelitist Delegating Behaviour. Here, especially perceived cultural practices of pronounced Uncertainty Avoidance and Future Orientation, weak In-group Collectivism combined with a positive view toward Institutional Collectivism and a negative one toward Performance Orientation seem to support high expectations of Non-elitist Delegating Behaviour on behalf of leaders and managers. Interestingly, a slightly positive correlation was in turn found for Performance Orientation practices and the subscale Participative Decision Making (in contrast to a non-significant relation for the overall scale).

All in all, compared with the strong impact of individual value preferences described above, perceptions of institutional and cultural practices in place seem to be of less importance for the shaping of students' participatory expectations. Our analyses also indicate that perceptions of cultural practices may differ considerably between individual students and countries.

\section{Socialising agents as role models}

Next, we looked at the influence of social agencies and respective role models. The results show positive correlations between both participative leadership factors (GLOBE and newly calculated dimensions including subscales) on the one hand and the perceived influence of family (e.g. parents), school (e.g. teachers) and peer group (e.g. friends) on the other hand (all with $>0.01 * *$ ). In other words, the stronger the influence of these factors, the more highly students value participative leadership. As for the original GLOBE second-order dimension, experiences with superiors during internships also contribute to participative leadership expectations. It is worth mentioning that opposed experiences during socialisation may have led to a positive assessment of participative leadership: Negative experiences with autocratic decision making in contexts such as family or school as well as positive role model experiences may eventually have contributed to the described effect.

In addition, experiences with some other role models seem to have a negative impact on students' leadership prototypes. The more frequently students refer to leadership examples from science and research, the less important participation seems to be as an aspect of their leadership ideals $(>0.01 * *)$. This may indicate that students perceive these role models to be individualistic rather than grouporiented, cooperative and participative. The results for stars in politics and other public role models spread through the media are pointing in the same direction, but with a weaker correlation $(>0.05 *)$.

As for the subscales of the new Participative Leadership dimension, the abovementioned role models from family, school and peer groups can be expected to enhance participative expectations with respect to Egalitarian Group Orientation and Participative Decision Making. In contrast, Non-elitist Delegating 
Behaviour seems to be especially inspired by negative leadership examples among radio and TV stars, politicians, business leaders, scientists and superiors.

We may conclude that while it is far from clear how role models related to characteristics of good vs. bad leadership are formed during the various stages and settings of socialisation, their differentiating influence should not be neglected and needs further consideration and in-depth analysis.

\section{Impact analysis for participative leadership expectations of CEE students}

To further explore the multifaceted influence of the above-mentioned single factors shaping the patterns of students' positive participative leadership expectations, we ran two linear regression models. Tables 6 and 7 show the models for participative leadership expectations of students based on the original GLOBE Participative Leadership dimension (Table 6) and the new, reconfigured dimension of Participative Leadership (Table 7).

Table 6: Regression model for CEE students' participative leadership expectations (based on GLOBE's original second-order dimension)

\begin{tabular}{|c|c|c|c|c|c|}
\hline \multirow[t]{2}{*}{ Model } & \multicolumn{2}{|c|}{$\begin{array}{l}\text { Non-standardized } \\
\text { Coefficient }\end{array}$} & \multirow{2}{*}{$\begin{array}{c}\text { Standardized } \\
\text { Coefficient }\end{array}$} & \multirow[t]{2}{*}{$\mathbf{T}$} & \multirow[t]{2}{*}{ Sig. } \\
\hline & $\begin{array}{c}\text { Regression } \\
\text { Coefficient } \\
\text { B }\end{array}$ & $\begin{array}{l}\text { Standard } \\
\text { Error }\end{array}$ & & & \\
\hline 1 (constant) & -1.880 & 1.063 & & -1.768 & 0.077 \\
\hline Field of Study & -0.035 & 0.016 & -0.041 & -2.212 & 0.027 \\
\hline Gender & -0.067 & 0.034 & -0.036 & -1.979 & 0.048 \\
\hline $\begin{array}{l}\text { Power Distance } \\
\text { Values }\end{array}$ & -0.252 & 0.021 & -0.243 & -11.916 & 0.000 \\
\hline $\begin{array}{l}\text { Assertiveness } \\
\text { Values }\end{array}$ & -0.169 & 0.020 & -0.173 & -8.457 & 0.000 \\
\hline
\end{tabular}




\begin{tabular}{|l|c|c|c|c|c|}
\hline $\begin{array}{l}\text { Gender Egalitarian } \\
\text { Values }\end{array}$ & 0.159 & 0.026 & 0.109 & 6.008 & 0.000 \\
\hline $\begin{array}{l}\text { In-group } \\
\text { Collectivism Values }\end{array}$ & 0.078 & 0.020 & 0.077 & 3.967 & 0.000 \\
\hline $\begin{array}{l}\text { Institutional } \\
\text { Collectivism Values }\end{array}$ & 0.083 & 0.021 & 0.075 & 3.934 & 0.000 \\
\hline $\begin{array}{l}\text { Uncertainty } \\
\text { Avoidance Values }\end{array}$ & -0.068 & 0.020 & -0.064 & -3.374 & 0.001 \\
\hline $\begin{array}{l}\text { Humane Orientation } \\
\text { Values }\end{array}$ & 0.072 & 0.024 & 0.061 & 3.013 & 0.003 \\
\hline $\begin{array}{l}\text { Uncertainty } \\
\text { Avoidance Country } \\
\text { Practices }\end{array}$ & 0.405 & 0.066 & 0.243 & 6.128 & 0.000 \\
\hline $\begin{array}{l}\text { Power Distance } \\
\text { Country Practices }\end{array}$ & 0.644 & 0.124 & 0.210 & 5.191 & 0.000 \\
\hline $\begin{array}{l}\text { Institutional } \\
\text { Collectivism } \\
\text { Country Practices }\end{array}$ & 0.037 & 0.010 & 0.089 & 3.719 & 0.000 \\
\hline $\begin{array}{l}\text { Role Model: } \\
\text { Teachers }\end{array}$ & 0.366 & 0.087 & 0.105 & 4.229 & 0.000 \\
\hline $\begin{array}{l}\text { Examples from } \\
\text { Science }\end{array}$ & 0.010 & -0.074 & & \\
\hline
\end{tabular}


Table 7: Regression model for CEE students' participative leadership expectations (based on re-configured second-order dimension) - to be placed here

\begin{tabular}{|c|c|c|c|c|c|}
\hline \multirow[t]{2}{*}{ Model } & \multicolumn{2}{|c|}{$\begin{array}{c}\text { Non-standardized } \\
\text { Coefficient }\end{array}$} & \multirow{2}{*}{$\begin{array}{c}\text { Standardized } \\
\text { Coefficient }\end{array}$} & \multirow[t]{2}{*}{$\mathbf{T}$} & \multirow[t]{2}{*}{ Sig. } \\
\hline & $\begin{array}{c}\text { Regression } \\
\text { Coefficient } \\
\text { B }\end{array}$ & $\begin{array}{l}\text { Standard } \\
\text { Error }\end{array}$ & & & \\
\hline $\begin{array}{ll}1 & \text { (constant) }\end{array}$ & 14.657 & 3.552 & & 4.127 & 0.000 \\
\hline Field of Study & -0.540 & 0.005 & -0.071 & -3.750 & 0.000 \\
\hline Age & 0.100 & 0.005 & 0.040 & 2.121 & 0.034 \\
\hline $\begin{array}{l}\text { Power Distance } \\
\text { Values }\end{array}$ & -0.189 & 0.020 & - 0.206 & - 9.361 & 0.000 \\
\hline $\begin{array}{l}\text { Gender Egalitarian } \\
\text { Values }\end{array}$ & 0.157 & 0.025 & 0.122 & 6.325 & 0.000 \\
\hline $\begin{array}{l}\text { Institutional } \\
\text { Collectivism Values }\end{array}$ & 0.093 & 0.020 & 0.095 & 4.703 & 0.000 \\
\hline $\begin{array}{l}\text { Assertiveness } \\
\text { Values }\end{array}$ & -0.080 & 0.019 & - 0.092 & -4.234 & 0.000 \\
\hline $\begin{array}{l}\text { In-group } \\
\text { Collectivism } \\
\text { Values }\end{array}$ & 0.072 & 0.019 & 0.081 & 3.749 & 0.000 \\
\hline $\begin{array}{l}\text { Uncertainty } \\
\text { Avoidance Values }\end{array}$ & -0.070 & 0.019 & -0.075 & - 3.720 & 0.000 \\
\hline $\begin{array}{l}\text { Performance } \\
\text { orientation Values }\end{array}$ & 0.060 & 0.022 & 0.059 & 2.753 & 0.006 \\
\hline $\begin{array}{l}\text { Humane Orientation } \\
\text { Values }\end{array}$ & 0.048 & 0.022 & 0.046 & 2.158 & 0.031 \\
\hline
\end{tabular}




\begin{tabular}{|l|c|c|c|c|c|}
\hline \begin{tabular}{l} 
In-group $\begin{array}{l}\text { Collectivism } \\
\text { Country Practices }\end{array}$ \\
\hline $\begin{array}{l}\text { Uncertainty } \\
\text { Avoidance Country } \\
\text { Practices }\end{array}$
\end{tabular} & -0.509 & 0.147 & -0.319 & -3.474 & 0.001 \\
\hline $\begin{array}{l}\text { Power Distance } \\
\text { Country Practices }\end{array}$ & -0.766 & 0.280 & -0.283 & -2.731 & 0.006 \\
\hline $\begin{array}{l}\text { Institutional } \\
\text { Collectivism } \\
\text { Country Practices }\end{array}$ & -0.360 & 0.139 & -0.118 & -2.590 & 0.010 \\
\hline & 0.032 & 0.008 & 0.104 & 3.942 & 0.000 \\
\hline Role Model: Parents & -0.036 & 0.009 & -0.098 & -4.015 & 0.000 \\
\hline $\begin{array}{l}\text { Role Model: } \\
\text { Examples from } \\
\text { Science }\end{array}$ & & & & & \\
\hline
\end{tabular}

The models explain between 20 and 30\% of the variance (RQ with 0.220 for the newly calculated Participative Leadership dimension, 0.300 for GLOBE's original one). The main factors in both models are:

- the rejection of Power Distance values, Assertiveness values and Uncertainty Avoidance values,

- a positive evaluation of In-group and Institutional Collectivism values, Gender Egalitarianism values and Humane Orientation values,

- an influence of the field of study, with participative ideals being more influential for the group of business economics students,

- a negative impact of role models from science and research, and

- a divergent but relevant influence of Uncertainty Avoidance country practices, Power Distance country practices and Institutional Collectivism country practices.

Moreover, some factor influences were only included in one of the two models, such as the positive impact of the role models teachers (original GLOBE dimension) or parents (re-configured dimension), a stronger preference for participative leadership by females (GLOBE) or older students (re-configured dimension), and the positive impact of students' individual values with respect to Performance Orientation (re-configured dimension). Additionally, In-group Collectivism country practices seem to negatively influence a positive valuation of participative leadership (reconfigured dimension). 
The most striking and somewhat puzzling difference between the two regression models is the completely different direction of influence of the perceived cultural practices. In the case of GLOBE's original Participative Leadership dimension, the three cultural factors included in the regression model are all positively associated, i.e. country-level perceptions of high Uncertainty Avoidance, Power Distance and Institutional Collectivism practices go hand in hand with students' high appreciation of participative leadership. In contrast, the regression model for the re-configured Participative Leadership dimension shows just negative correlations for the included cultural practices dimensions.

\section{Comparison between students and managers}

Last but not least, we compared the GLOBE Student data with the results of the original GLOBE study regarding leadership ideals of middle managers. We used the GLOBE results for an overall assessment and for selected countries.

The data show that participative leadership expectations of the 7-country CEE student sample on average bear more resemblance to the CEE managers' as well as to the GLOBE world-wide sample's ideal of participative leadership than do other leadership prototypes. More in detail, the data allow a direct comparison of the countries for which data of managers as well as of students are available. Within the GLOBE project, data were sampled from Austrian, German, Polish and Slovenian managers (House 2002; House et al. 2004). Moreover, data for Romanian middle managers became available via the GLOBE Student project (Bakacsi et al. 2006). Table 8 shows the results of the student-manager comparison for these five countries.

Table 8: Participative leadership expectations of students and middle managers by country

\begin{tabular}{|c|c|c|c|}
\hline Country & Students $^{1)}$ & Middle Managers & Gap $^{\text {4) }}$ \\
\hline Austria & 5.30 & $6,00^{2)}$ & $-0,70$ \\
\hline Germany & 5.29 & $5,87^{2)}$ & -0.58 \\
\hline Poland & 4.86 & $5,05^{2)}$ & -0.19 \\
\hline Romania & 4.77 & $4,89^{3)}$ & -0.12 \\
\hline Slovenia & 4.50 & $5,42^{2)}$ & -0.92 \\
\hline
\end{tabular}

Notes: ${ }^{1)}$ source: GLOBE Student database (original second-order dimension); ${ }^{2)}$ source: House et al. (2004); ${ }^{3)}$ source: Bakacsi et al. (2006); ${ }^{4)}$ gap calculated as students minus managers score.

The data show a common tendency across countries that managers rank participative leadership more highly than the students in the same countries do, although both managers' and students' evaluations of participative leadership are clearly positive (mean scores above 4.0). Yet, there are also striking 
differences between the countries. In Germany, Austria and Slovenia students display drastically lower participative leadership expectations than managers, while the differences are less pronounced for Poland and Romania.

\section{Summary results and conclusions}

With respect to our seven hypotheses the results allow the following conclusions:

(1)There is full support for Hypothesis 1, with regard to CEE students' desire for participative leadership as well as their clear rejection of autocratic leadership behaviour. With a seven-country mean of 4.97 the degree of expected Participative Leadership significantly exceeds the medium of 4.0. Nevertheless, Participative Leadership is not as strongly desired by CEE students as are other styles, such as Charismatic/Value-based or Team-oriented behaviours. Analyses based on the new re-configured participation dimension also support Hypothesis 1 and so do the three new subscales.

(2)As hypothesised, Austrian and German students display significantly higher expectations in favour of participative leadership than their counterparts from the other CEE countries. Restrictions in support of Hypothesis 2 have to be made for Slovakia, especially with respect to the newly calculated dimension. Furthermore, the re-configured factor set does not confirm the difference between the Germanic and East European countries as clearly as GLOBE's original scale.

(3) As for Hypothesis 3, participative leadership expectations were found to differ according to gender and field of study in the expected way: Females as well as students of business economics displayed a comparatively stronger desire for participative leadership styles than other students. The influence of age as well as number of study terms in the direction of younger students showing a stronger wish for participative leadership has to be rejected for the following reasons: (1) Significant differences between age groups did not show in the overall measures, only in one of the subscales, (2) Age as a factor showed in only one of the regression models, suggesting a positive correlation with participative leadership expectations.

(4)Hypothesis 4 found full support by the data. In other words individual value preferences seem to be a strong predictor of students' participative leadership expectations. More precisely, low scores on power stratification and assertiveness values, as well as high scores on values related to gender equality, humanity and collectivism go hand in hand with students' strong preferences for participative leadership. Thus, Hypothesis 4 is supported for all specified societal culture dimensions in 
the anticipated direction. In addition, the negative impact of uncertainty avoidance values has to be mentioned.

(5)The institutional and cultural context, specifically when measured by means of the individual perceptions of culturally relevant country practices, shows a significant influence on participative leadership expectations, but in most cases not in the anticipated directions. Contrary to assumptions, high expectations regarding participative leadership go hand in hand with high scores on assertiveness practices, as well as with low scores on practices related to in-group collectivism and gender equality. The hypothesised positive influence of perceived institutional rules of collectivism, as well as the anticipated negative relationship between perceptions of power distance and expectations of participative leadership are supported by the data, yet with an overall lower impact than assumed. In addition, the data suggest that high uncertainty avoidance and future orientation practices support the participative leadership ideal. These findings are almost opposite to what we found for individual value preferences. Possibly, students' observation of restrictive practices (including their negative consequences) regarding the distribution of power and equality among the genders, as well as of the dominance of the individual over the collective have led them to develop values in sharp contrast to the perceived status quo. Furthermore, it seems typical for the young to ideologically depart from their parent generation. More research is definitely needed in this area. In conclusion, Hypothesis 5 is only partially supported by the data, as societal culture practices do have an impact on participative leadership expectations, yet the directions seem partly unclear and also contradictory, according to the regression analyses ${ }^{12}$.

(6)Hypothesis 6 concerned the influence of social agencies and found partial support by the data. Especially role models and experiences from family (parents), school (teachers) and peer groups (friends) seem to contribute to students' participative leadership expectations. The assumed negative influence of examples from politics was significant, but less relevant compared to other influence factors. Contrary to assumptions, examples from science and research also showed a negative impact.

(7)As stated in Hypothesis 7, CEE students' participative leadership expectations were positive yet lower than managers' preferences for all seven countries represented in our study. A possible explanation for this tendency could be the following: It may need personal experience and

12 The well-known problems of GLOBE's measurement of culture, specifically the critical relations between values and practices (see introductory article of this special issue by Čater, Lang and Szabo), may also be a reason for the revealed differences between correlation and regression analyses. All relevant practices dimensions show strong negative correlations for the value-practice relationship. 
organisational practice to fully appreciate the benefits of participative leadership behaviour. This interpretation is supported by studies showing that older, more experienced managers employ participative strategies more often than their younger, still relatively inexperienced colleagues do (e.g. Reber et al. 2000 found a weak yet significantly positive correlation between age and managers' mean level of participation in decision making).

\section{Discussion and implications for future research}

This article provides a first comparative view on leadership expectations of Central and East European students in relation to various influence factors, among them individually held cultural values and perceptions of cultural institutions and practices. It shows the relevance of the "culture argument" in several ways. First of all, students' perceptions of their cultures as well as their individual value preferences are close to the relevant regional culture clusters (Germanic and East European), and partly to the country cultures the students belong to, as proposed by the findings of the GLOBE study for middle managers. Second, leadership expectations and prototypes of good (and bad) leadership behaviours are culturally bound and can be well explained by a combination of different societal culture dimensions. Third, what students consider to be ideal types of leadership differs between the analysed country cultures. Fourth, the data provide some support for the influence of cultural institutions, such as family, school, and peer group, as well as the media on the formation of young persons' leadership prototypes. Finally, the relative similarities among students and middle managers support the notion of stability of leadership styles over time. The differences between the two cohorts point to the fact that students may be willing to accept a lower level of participation than today's middle managers, at least at the beginning of their careers.

Future comparative studies as well as in-depth analyses may explore the country profiles and differences between them in more detail. Moreover, the formation and respective mechanisms of influence on leadership prototypes may be in the centre of future comparative research. And finally, comparative studies of valuebased decision making preferences may be of interest, especially in light of the current public debate across countries regarding corporate social responsibility. 


\section{Appendix}

Appendix A: Participative leadership items in the GLOBE project

\begin{tabular}{|c|c|c|c|c|}
\hline $\begin{array}{c}\text { Global } \\
\text { Leadership } \\
\text { Dimension } \\
\text { (Second-order) }\end{array}$ & $\begin{array}{c}\text { Primary } \\
\text { Leadership } \\
\text { Dimensions } \\
\text { (First-order) }\end{array}$ & $\begin{array}{c}\text { Item } \\
\text { Numbe } \\
\mathbf{r}\end{array}$ & Item & Item Description \\
\hline \multirow{2}{*}{$\begin{array}{l}\text { Participative } \\
\text { (all items } \\
\text { reverse-scored) }\end{array}$} & \multirow[t]{6}{*}{ Autocratic } & $2-4$ & Bossy & $\begin{array}{l}\text { Tells subordinates what to do } \\
\text { in a commanding way }\end{array}$ \\
\hline & & $2-36$ & Autocratic & $\begin{array}{l}\text { Makes decisions in } \\
\text { dictatorial way }\end{array}$ \\
\hline \multirow{8}{*}{$\begin{array}{l}\text { Definition: } \\
\text { “A leadership } \\
\text { dimension that } \\
\text { reflects the } \\
\text { degree to which } \\
\text { managers } \\
\text { involve others in } \\
\text { making and } \\
\text { implementing } \\
\text { decisions” } \\
\text { (Dorfman et al. } \\
\text { 2004: 675) }\end{array}$} & & $4-33$ & $\begin{array}{c}\text { Domineerin } \\
\mathrm{g}\end{array}$ & Inclined to dominate others \\
\hline & & $4-37$ & Elitist & $\begin{array}{l}\text { Believes that a small number } \\
\text { of people with similar } \\
\text { backgrounds are superior and } \\
\text { should enjoy privileges }\end{array}$ \\
\hline & & $4-48$ & Ruler & $\begin{array}{l}\text { Is in charge and does not } \\
\text { tolerate disagreement or } \\
\text { questioning; gives orders }\end{array}$ \\
\hline & & $4-54$ & Dictatorial & $\begin{array}{l}\text { Forces her/his values and } \\
\text { opinions on others }\end{array}$ \\
\hline & \multirow[t]{4}{*}{$\begin{array}{l}\text { Participative } \\
\text { (all items } \\
\text { reverse-scored) }\end{array}$} & $4-13$ & $\begin{array}{c}\text { Individually } \\
\text { oriented }\end{array}$ & $\begin{array}{l}\text { Concerned with and places } \\
\text { high value on preserving } \\
\text { individual rather than group } \\
\text { needs }\end{array}$ \\
\hline & & $4-14$ & $\begin{array}{c}\text { Non- } \\
\text { egalitarian }\end{array}$ & $\begin{array}{l}\text { Believes that all individuals } \\
\text { are not equal and only some } \\
\text { should have equal rights and } \\
\text { privileges }\end{array}$ \\
\hline & & $4-43$ & $\begin{array}{l}\text { Micro- } \\
\text { manager }\end{array}$ & $\begin{array}{l}\text { An extremely close } \\
\text { supervisor, one who insists } \\
\text { on making all decisions }\end{array}$ \\
\hline & & $4-44$ & $\begin{array}{c}\text { Non- } \\
\text { delegator }\end{array}$ & $\begin{array}{l}\text { Unwilling or unable to } \\
\text { relinquish control of projects } \\
\text { or tasks }\end{array}$ \\
\hline
\end{tabular}

Appendix B: Additional participative leadership items in the GLOBE Student project

\begin{tabular}{|c|c|l|}
\hline $\begin{array}{c}\text { Item } \\
\text { Number }\end{array}$ & \multicolumn{1}{|c|}{ Item } & Item Description \\
\hline $2-30$ & Collaborative & Works jointly with others \\
\hline $2-45$ & Consultative & $\begin{array}{l}\text { Consults with others before making plans or taking } \\
\text { action }\end{array}$ \\
\hline $4-7$ & Non-cooperative & Unwilling to work jointly with others \\
\hline $4-29$ & Non-participative & Does not participate with others \\
\hline
\end{tabular}




\section{References}

Alt, R./Lang, R. (2004): Anforderungen an die Führungskompetenzen von Managern im Transformationsprozess ausgewählter MOEL, in: Zschiedrich, H./Schmeisser, W./Hummel, T.R. (eds.): Internationales Management in den Märkten Mittel- und Osteuropas. München/Mering: Hampp, 111-132.

Bakacsi, G./Catana, A./Catana, D./et al. (2006): GLOBE Romania. Final report on the results of the GLOBE Romania project (unpublished).

Bakacsi, G./Takács, S./Karácsonyi, A./Imrek, V. (2002): East European Cluster: Tradition and transition, in: Journal of World Business, 37, 1, 69-80.

Brodbeck, F.C./Frese, M./44 co-authors (2000): Cultural variation of leadership prototypes across 22 European countries, in: Journal of Occupational and Organizational Psychology, 73, 1, 1-29.

Čater, T./Lang, R. (eds.) (2011): Values and leadership expectations of future managers from transforming societies, Organisationswissenschaftliche Schriftenreihe der TU Chemnitz, No. 16, August 2011. Chemnitz: Chemnitz University of Technology. (http://www.tuchemnitz.de/wirtschaft/bwl5/forschung/schriften/doc/16.pdf)

Chhokar, J.S./Brodbeck, F.C./House, R.J. (eds.) (2007): Culture and leadership across the world: The GLOBE book of in-depth studies of 25 societies. Mahwah, NJ: Lawrence Erlbaum Associates.

Dickson, M.W./Castaño, N./Magomaeva, A./Den Hartog, D.N. (2012): Conceptualizing leadership across cultures, in: Journal of World Business, 47, 4, 483-492.

Dorfman, P.W./ House, R.J. (2004): Cultural influences on organizational leadership: Literature review, theoretical rationale, and GLOBE project goals, in: House, R.J./Hanges, P.J./Javidan, M./Dorfman, P.W./Gupta, V. (eds.): Culture, leadership, and organizations: The Globe study of 62 societies. Thousand Oaks: Sage, 51-73.

Dorfman, P.W./Hanges, P.J./Brodbeck, F.C. (2004): Leadership and cultural variation: The identification of culturally endorsed leadership profiles, in: House, R.J./Hanges, P.J./Javidan, M./Dorfman, P.W./Gupta, V. (eds.): Culture, leadership, and organizations: The Globe study of 62 societies. Thousand Oaks: Sage, 669-719.

Dorfman, P.W./Javidan, M./Hanges, P.J./Dastmalchian, A./House, R.J. (2012): GLOBE: A twenty year journey into the intriguing world of culture and leadership, in: Journal of World Business 47, 4, 504-518.

Edwards, V./Lawrence, P. (2000): Management in Eastern Europe. Basingstoke: Palgrave.

GLOBE Foundation (2006): Syntax for GLOBE national culture, organizational culture, and leadership scales. http://www.hangeslab.umd.edu/index_files/Syntax_for_GLOBE_Leadership_ and_Culture_Scales.pdf, dl: August 3, 2006.

Hanges, P.J./Dickson, M.W. (2004): The development and validation of the GLOBE culture and leadership scales, in: House, R.J./Hanges, P.J./Javidan, M./Dorfman, P.W./Gupta, V. (eds.): Culture, leadership, and organizations: The Globe study of 62 societies. Thousand Oaks: Sage, 122-151.

Hofstede, G. (1991): Cultures and organizations: Software of the mind. Maidenhead, UK: McGrawHill.

House, R.J. (2002): Global leadership and organizational behavior effectiveness research program: Results with special respect to Eastern Europe, in: Lang, R. (ed.): Personalmanagement im Transformationsprozess. $V^{\text {th }}$ Chemnitz Eastforum, München/Mering: Hampp, 43-62. 
House, R.J./Hanges, P.J./Javidan, M./Dorfman, P.W./Gupta, V. (eds.) (2004): Culture, leadership, and organizations: The GLOBE study of 62 societies. Thousand Oaks: Sage.

House, R.J./Hanges, P.J./Ruiz-Quintanilla, S.A./Dorfman, P.W./Javidan, M./Dickson, M.W./Gupta, V./GLOBE Country Co-investigators (1999): Cultural influences on leadership and organizations: Project GLOBE, in: Mobley, W.H./Gessner, M.J./Arnold, V. (eds.): Advances in Global Leadership, 1. Stamford, CT: JAI Press, 171-233.

Javidan, M./Dorfman, P.W./de Luque, M.S./House, R.J. (2006): In the eye of the beholder: Cross cultural lessons in leadership from project GLOBE, in: Academy of Management Perspectives, 20, 1, 67-90.

Keating, M.A./Martin, G.S./Szabo, E. (2002): Do managers and students share the same perceptions of societal culture?, in: International Journal of Intercultural Relations, 26, 6, 633-652.

Lang, R./Alas, R./Alt, R./Catana, D./Hartz, R. (2005): Leadership in transformation: Between local embeddedness and global challenges, in: Journal of Cross-Cultural Competence and Management, 4, 215-46.

Lang, R./Catana, A./Catana, D./Steyrer, J. (2008): Impacts of motives and leadership attributes of entrepreneurs and managers on followers' commitment in transforming countries: A comparison of Romania, East Germany and Austria, in: Jurczek, P./Niedobitek, M. (eds.): Europäische Forschungsperspektiven: Elemente einer Europawissenschaft 2008. Berlin: Duncker \& Humblot, 109-135.

Lindert, K. (1996): Führungskonzeptionen im Wandel: Eine interkulturelle und intertemporale Studie. Gemeinsamkeiten und Unterschiede west- und osteuropäischer Führungskräfte, in: Lang, R. (ed.): Wandel von Unternehmenskulturen in Ostdeutschland und Osteuropa. München/Mering: Hampp, 91-106.

Reber, G./Jago, A.G./Auer-Rizzi, W./Szabo, E. (2000): Führungsstile in sieben Ländern Europas - Ein interkultureller Vergleich, in: Regnet, E./Hofmann, L.M. (eds.): Personalmanagement in Europa. Göttingen: Verlag für Angewandte Psychologie, 154-173.

Remišová, A./ Lašáková, A. (2011): GLOBE Student research project in Slovakia - preliminary findings, in: Čater, T./Lang, R. (eds.): Values and leadership expectations of future managers from transforming societies, Organisationswissenschaftliche Schriftenreihe der TU Chemnitz, No. 16, August 2011. Chemnitz: Chemnitz University of Technology, 32-49. (http://www.tuchemnitz.de/wirtschaft/bwl5/forschung/schriften/doc/16.pdf).

Steger, T./Winkler, I. (eds.) (2003): Leaders and leadership in Central and Eastern Europe. Special issue, in: Journal for East European Management Studies, 8. München/Mering: Hampp.

Steyrer, J./Hartz, R./Schiffinger, M. (2006): Leadership in transformation between local embeddedness and global challenges, in: Journal for East Europaean Management Studies, 11, 2, 113-139.

Suutari, V./Riusala, K. (2001): Leadership styles in Central Eastern Europe: Experiences of Finnish expatriates in the Czech Republic, Hungary and Poland, in: Scandinavian Journal of Management, 17, 2, 249-280.

Szabo, E./Brodbeck, F.C./Den Hartog, D.N./Reber, G./Weibler, J./Wunderer, R. (2002): The Germanic Europe cluster: Where employees have a voice, in: Journal of World Business, 37, 1, 55-68. 
Szabo, E./Reber, G./Weibler, J./Brodbeck, F.C./Wunderer, R. (2001): Values and behavior orientation in leadership studies: Reflections based on findings in three German-speaking countries, in: Leadership Quarterly, 12, 2, 219-244.

Weibler, J./Brodbeck, F.C./Szabo, E./Reber, G./Wunderer, R./Moosmann, O. (2000): Führung in kulturverwandten Regionen. Gemeinsamkeiten und Unterschiede bei Führungsidealen in Deutschland, Österreich und der Schweiz, in: Die Betriebswirtschaft, 60, 5, 588-606. 